\title{
Evaluation of The Relevance of Urgency in Dermatological Patients Admitted to The Emergency Department with The Relationship Between Anxiety, Depression Levels and Dermatological Quality of Life: A Prospective Observational Study
}

\author{
Acil Servise Başvuran Dermatolojik Hastaların Aciliyet \\ Uygunluğunun; Anksiyete, Depresyon Düzeyleri Ve Dermatolojik \\ Yaşam Kalitesi Arasındaki İlișki İle Değerlendirilmesi: Prospektif \\ Gözlemsel Bir Çalışma
}

Hatice Kaya ${ }^{1}$, Onur Karakayali²

\begin{abstract}
'Sağlık Bilimleri Üniversitesi, Derince Eğitim ve Araştırma Hastanesi, Dermatoloji Kliniği, Kocaeli ${ }^{2}$ Sağlık Bilimleri Üniversitesi, Derince Eğitim ve Araştırma Hastanesi, Acil Tıp Kliniği, Kocaeli
\end{abstract}

\begin{abstract}
Objectives: In this study, it was aimed to define the demographic data of the patients admitted to the emergency clinics with dermatological complaints, to determine the rate of the true dermatologic emergency cases, the dermatology life quality index, and to define the reasons why patients without dermatological emergencies admitted to Emergency clinics, their psycho-social backgrounds with Beck Anxiety and Depression Inventory.

Materials and Methods: It was a single-center prospective observational and questionnairebased study. The patients older than 18 years of age who admitted to the emergency department due to dermatological emergencies were included in the study. In this study, the patients who were admitted to the emergency department were consulted by the dermatology specialist after their initial diagnosis and treatment was done by the emergency physicians. Demographic data, dermatology life quality index, scores of Beck Anxiety and Depression Inventory were recorded.

Results: The average age of 200 patients was $40.5(16.39)$ and 116 of the patients (58\%) were female. The duration of the most frequent complaint was 1 month and over $(n=58,29 \%)$. The true dermatological patient group was $29.5 \%$ of all patients. The most common reason for the hospital admission was that the patients thought that their condition was urgent $(47.50 \%)$. The most common complaint for hospital admission was urticaria (24\%). According to dermatology life quality index, 79 (39.5\%) patients were affected moderately. The mean value of all patients was $15.22+12.56$ according to the Beck anxiety inventory, while the mean value was 12.88 .9 according to the Beck depression inventory. When the patients were divided into two groups according to Beck depression-anxiety inventory and dermatology life quality index, there was no statistically significant difference between the two groups in terms of gender, age, marital status, education level, income level, duration of complaint, and the reason for admission. However, there was a statistically significant difference between groups in terms of gender according to Beck anxiety inventory $(\mathrm{p}=0.029)$.

Conclusion: In our study, the patients coming from the emergency department were evaluated by dermatology physician in a short time, so more accurate diagnosis and rapid treatment opportunities were provided and unnecessary medical approaches and costs were prevented. We believe that increased anxiety levels are an important factor in patients admitting to the emergency department. Therefore, awareness-raising campaigns should be beneficial in preventing frequent admission by social media and hospital-based studies focusing on this issue.

Keywords: Dermatologic emergency, emergency department, anxiety, depression
\end{abstract}

\section{$\ddot{\mathrm{O} z}$}

Amaç: Çalıșmamızda dermatolojik şikayetlerle acil kliniğine bașvuran hastaların demografik verilerinin tanımlanması, gerçek dermatolojik acil vakaların oranının belirlenmesi ve Beck anksiyete ve depresyon ölçekleri ile başvuru nedenlerinin psiko-sosyal zemininin ve acil servise acil olmayan hastaların bașvuru gerekçelerinin tanımlanması amaçlanmıștır.

Materyal ve Metot: Prospektif gözlemsel ve anket çalışma araştırma tek merkez olarak 3 aylık 
Evaluation of The Relevance of Urgency in Dermatological Patients Admitted to The Emergency Department with The Relationship Between Anxiety, Depression Levels and Dermatological Quality of Life: A Prospective Observational Study

dönemde acil tıp kliniğine dermatolojik aciller nedeniyle başvuran 18 yaşından büyük hastalar dahil edilerek yapıldı. Çalıșmada acil servise başvuran bu hastalar ilk tanı ve tedavileri acil tıp hekimleri tarafından yapıldıktan sonra dermatoloji uzmanına konsulte edildi. Hastaların demografik verileri, dermatolojik yașam indeksi, Beck anksiyete ve depresyon ölçeği kayıt altına alındı.

Bulgular: 200 hastanın ortalama yaşı 40,5 $(16,39)$, 116' sı (\%58) kadındı. En sık bașvuru grubunun şikayetleri 1 ay ve üzerinde $(n=58, \% 29)$ idi. Gerçek dermatolojik hasta grubu tüm hastaların \%29,5' i idi. En sık bașvuru nedeni hastaların durumlarının acil olduğunu düșünmeleri $(\% 47,50)$ ve klinik tanıları en sık ürtiker (\%24) idi. Hastalar dermatolojik yaşam kalite indeksine göre; 79 ' unun $(\% 39,5)$ orta derecede etkilendiği gözlendi. Beck anksiyete puan ölçeğine göre tüm hastaların ortalama değeri 15,22 12,56' idi. Beck depresyon sınıflamasına göre hastaların ortalaması 12,8 +8,9' idi. Hastalar Beck depresyon-anksiyete ölçeği ve dermatolojik yaşam indeksine göre hafif ve orta-şiddetli olarak 2 gruba ayrıldığında her iki grup arasında cinsiyet, yaș, medeni durum, eğitim durumu, gelir düzeyi, şikâyet başvuru süresi, bașvuru sebebi arasında istatistiksel olarak anlamlı fark tespit edilmedi, sadece Beck anksiyete depresyon ölçeğine göre cinsiyet farklılıklarına göre istatistiksel olarak anlamlı fark tespit edildi $(\mathrm{p}=0,029)$.

Sonuç: Çalışmamız acilden gelen hastaların kısa sürede dermatoloji hekimi tarafından değerlendirilmesi ile daha doğru tanı, hızlı tedavi imkânı sağlaması yanı sıra gereksiz tıbbi yaklașımların ve masrafların önlenmesinde fayda sağlamıștır. Hastaların acile başvurularında anksiyete düzeylerinin yüksek olmasının önemli bir faktör olduğu, bu nedenle bilinçlendirme çalışmalarının gerek sosyal medya gerek hastane temelli çalışmalarla bu noktaya değinilerek artırılması sık başvurunun önlenmesinde fayda sağlayacaktır kanaatindeyiz.

Anahtar Kelimeler: Dermatolojik aciller, acil servis, anksiyete, depresyon

Yazıșma Adresi / Correspondence:

Dr. Onur Karakayali

e-mail: dr_onurkarakayali@hotmail.com

Date of submission: 22.05.2019

Date of admission: 29.05 .2019

\section{Introduction}

Although dermatological diseases are not life-threatening conditions, they can affect the psychosocial status of individuals and their daily work-home-social life activities negatively. Dermatological emergencies are defined as a group of diseases which are vitally important, more serious and life-threatening and require immediate intervention. Skin manifestations may be secondary to a systemic disease or there may also be primary diseases of the skin.

Emergency clinics are an important part of the health system. It is essential to reduce time loss with an effective triage method and to provide the necessary rapid approach to the individuals who are urgent. About $5-8 \%$ of the admissions to emergency departments are dermatological diseases. Studies conducted in hospitals with dermatologic emergency units reported that $49 \%$ of admissions in Spain and $82 \%$ of admissions in the USA were not true dermatologic emergency cases. ${ }^{1,2}$ The admission to any branch of the emergency department including dermatology is not only related to the medical condition but it is often depended on the geographic, climatic, socioeconomic, cultural and existing healthcare systems of the societies. ${ }^{3}$ Although dermatologic diseases are not usually life threatening, they may have a negative impact on the quality of life of individuals. In our country, although few epidemiological studies are available about the admissions to the emergency departments regarding 
Evaluation of The Relevance of Urgency in Dermatological Patients Admitted to The Emergency Department with The Relationship Between Anxiety, Depression Levels and Dermatological Quality of Life: A Prospective Observational Study

dermatological reasons, there is no study that evaluates depression, anxiety, and quality of life in terms of dermatology. 4

In this study, it was aimed to define the demographic data of the patients admitted to the emergency clinics with dermatological complaints, to determine the rate of the true dermatologic emergency cases, Beck anxiety and the dermatology life quality index, and to define the reasons why patients without dermatologic emergencies admitted to emergency clinics, to determine their psycho-social backgrounds with Beck Anxiety and Depression scales.

\section{Materials and Methods}

Our study was a single-center prospective observational and questionnairebased study. Patients who admitted to the adult emergency department of Kocaeli Derince Training and Research Hospital with any dermatological complaints between June and September 2018, who were older than 18 years of age, who had enough mental level to understand and answer the questionnaire, and who had no psychiatric diseases, were included in the study. The local ethics committee approval was obtained from Diyarbakir Gazi Yaşargil Training and Research Hospital Turkey (105/2018).

Because the dermatological patients admitted to hospital in summer more than in winter, the patients in the 3-month summer period were included in the study by aiming to reach more patients in order to understand whether they require an accurate dermatological emergency. In the study, the patients who admitted to the emergency room were evaluated by routine evaluation process, the initial diagnosis and treatment were made by emergency medicine physicians, and then those who arrived at 8.oo17.0o hours were consulted to the dermatology outpatient clinic on the same day, while those who arrived emergency services after working hours were consulted to the dermatology outpatient clinic on the next day.

The patients were re-evaluated in the dermatology outpatient clinic according to the study protocol by using Beck Depression and Anxiety Inventory, Dermatology Life Quality Index. The results and demographic and social status information were recorded. All patients were evaluated by the same dermatologist.

Dermatology Quality of Life Index (DQLI): It is a scale which is an applicable to all dermatological diseases and includes totally 10 questions with 4 possible responses in terms of symptoms, feeling of sickness, daily activities, recreation, school-work life, personal relationships, and treatment process. In general, it is aimed to understand the social and physical effect of the disease on the patient in the last week. A high score indicates that the quality of life of the patient is affected. The total score is ranged from o to 30. o-5 points; no effect or small at all on patient's life, 5-11 points; moderate effect on patient's life, and above 11 points; very large effect on patient's life. The Turkish validity and reliability studies of the scale were performed. ${ }^{5}$

Beck Anxiety Inventory (BAI): BAI is a 21-question multiple-choice self-report inventory, which is used to measure anxiety levels of individuals. Each item is scored between o-3 with a 4-point Likert scale. High score is associated with the severity of anxiety. Validity and reliability studies were conducted in Turkey. 
Evaluation of The Relevance of Urgency in Dermatological Patients Admitted to The Emergency Department with The Relationship Between Anxiety, Depression Levels and Dermatological Quality of Life: A Prospective Observational Study

Beck Depression Inventory (BDI): This is the self-assessment scale to determine the level of depression in individuals. This form, consisting of 21 questions, provides 4 Likert-type measurements. Each item is scored between $0-3$, and then the total score is determined. o to 9;

minimal depression, 10-16; mild, 17-29; moderate, 30 to 63; and severe depression. Adaptation, validity and reliability studies were conducted for Turkish society. ${ }^{6}$

\section{Statistical Analysis:}

SPSS.17 package program was used for statistical analysis. Sample size calculation was carried out the $G$ power program with an assumption of $\alpha: 0,05$ and $\beta: 0,80$ and effect size of o,20 was used. The requisite sample size was calculated as 200.7 KolmogorovSmirnov test was used to test whether the variables were normal or not. Categorical data are expressed as frequency and percentage, and continuous data as an arithmetic mean \pm standard deviation. Chi-square, student t-test, correlation and regression analyses were used for data analysis. P value below 0.05 was considered significant.

\section{Results}

A total of 200 patients were included in the study. $116(58 \%)$ of the patients were female and 84 were male $(42 \%)$. The mean age of the patients was $40.50( \pm 16.39)$, and the minimum age was 17 years. When the demographic data of the patients were examined, $137(68.50 \%)$ were married, $53(26.50 \%)$ were single, 10 (5\%) were widowed, and $18(9 \%)$ were illiterate, $85(42.50 \%)$ were primary / secondary school graduates, 97 $(48.50 \%)$ were high school / university graduates. $128(64 \%)$ of all patients were not working actively and 72 (36\%) were working. $70.50 \%$ of the patients were living in the provincial center. When the income status of the patients was examined, $127(63.50 \%)$ of the patients had no income or minimum wage. It was observed that most of the patients $(22 \%)$ were admitted to the emergency department on Sunday and $54.50 \%$ of the patients were admitted to the emergency department when health staff was off the clock.

When comorbid diseases of all patients were examined, $76.50 \%(n=153)$ did not have comorbidities. The distribution of patients regarding complaints is summarized in Table 1.

Table 1. The distribution of patients regarding complaints

\begin{tabular}{|l|c|c|}
\hline & $\mathbf{n}$ & $\%$ \\
\hline Itching & 54 & 38.50 \\
\hline Rash and skin eruption & 80 & 40 \\
\hline Burn & 5 & 2.50 \\
\hline Pain-irritancy-stinging & 35 & 17.50 \\
\hline Hair loss & 3 & 1.50 \\
\hline
\end{tabular}

When the complaints of the patients were examined according to the time of onset, the most frequent admission group included the patients whose complaints lasted one month or more $(\mathrm{n}=58,29 \%)$ The group of patients with acute symptoms 
Evaluation of The Relevance of Urgency in Dermatological Patients Admitted to The Emergency Department with The Relationship Between Anxiety, Depression Levels and Dermatological Quality of Life: A Prospective Observational Study

included the patients whose complaints lasted than 3 days $(\mathrm{n}=54,27 \%)$. The main reasons for the admission are summarized in Table 2.

Table 2. Distribution of the reasons for the admission to the emergency department in the study group.

\begin{tabular}{|l|c|c|}
\hline & n & \% \\
\hline They thought they were urgent. & 87 & 43.50 \\
\hline $\begin{array}{l}\text { They couldn't get an appointment from the outpatient } \\
\text { clinic. }\end{array}$ & 58 & 29 \\
\hline $\begin{array}{l}\text { They couldn't come in during the daytime because they } \\
\text { worked }\end{array}$ & 22 & 11 \\
\hline Other & 22 & 11 \\
\hline Dispatch from external center & 11 & 5.50 \\
\hline
\end{tabular}

The number of patients with true dermatological emergencies was 59 (29.50\%) according to the duration of symptoms and clinical emergencies of patients. 141 (70.50\%) of the patients did not have a medical history about the admission to the emergency department with similar complaints. The diagnoses of the patients made by dermatologists are summarized in Table 3. The diagnoses of 95 patients in the emergency department $(47.50 \%)$ were like the clinical diagnosis of the dermatology specialist.

Table 3. Distribution of dermatological clinical diagnoses of the study group

\begin{tabular}{|l|c|c|}
\hline & n & \% \\
\hline Urticaria & 48 & 24 \\
\hline Contact dermatitis & 26 & 13 \\
\hline Zoster & 20 & 10 \\
\hline Other & 20 & 10 \\
\hline pruritus & 18 & 9 \\
\hline Tinea & 12 & 6 \\
\hline Insect bite & 11 & 3.50 \\
\hline Cellulite & 9 & 4.50 \\
\hline Abscess, folliculitis & 9 & 4.50 \\
\hline Xerosis cutis & 8 & 4 \\
\hline Scabies & 7 & 3.50 \\
\hline Drug Rash & 6 & 3 \\
\hline Acne & 4 & 2 \\
\hline Pregnancy Rash & 2 & 1 \\
\hline
\end{tabular}


When patients are grouped according to dermatology quality of life index; It was observed that $79(39.50 \%)$ patients were affected moderately (5-11 points), and 76 $(38 \%)$ were affected severely ( $>11$ points), and $45(22.50 \%)$ were not affected by the disease (o-5 points). When the patients were divided into two groups as mild and moderate-severity according to DQLI , there was no statistically significant difference between the two groups in terms of gender, age, marital status, educational status, income level, duration of complaint and the reason of admission $(\mathrm{p}=0.601, \mathrm{p}=0.592$, $\mathrm{p}=0.562, \mathrm{p}=0.362, \mathrm{p}=0.546, \mathrm{p}=0.471, \mathrm{p}=0.999$, respectively).

The mean value of all patients was $15.22 \pm 12.56$ according to the Beck Anxiety Inventory scores. According to Beck Anxiety Inventory classification; 70 patients (35\%) was in minimal anxiety group with $0-7$ points, 50 patients $(25 \%)$ was in mild anxiety group with 8-15 points, $32(20 \%)$ was in moderate anxiety group with $16-25$ points, $48(24 \%)$ was in the severe anxiety group with 26-63. When the patients were divided into two groups as mild and moderate-severity according to the Beck Anxiety Inventory, there were statistically significant differences between the two groups according to gender, age, marital status, education level, income level, duration of complaints, admission time and gender $(\mathrm{p}=0.029)$, while there were no statistically significant differences in the others ( $\mathrm{p}=0.296, \mathrm{p}=0.149, \mathrm{p}=0.826, \mathrm{p}=0.816, \mathrm{p}=0.731, \mathrm{p}=0.145$, respectively).

According to Beck Anxiety Inventory, moderate-severe anxiety was higher in females than in males $(\mathrm{n}=54$ vs. $\mathrm{n}=26)$. According to the Beck Depression Inventory, the mean of the patients was $12.80 \pm 8.91$. According to this classification, 77 patients $(38.50 \%)$ had minimal depression, 61 (30.50\%) had mild, 48 (24\%) had moderate, and $13(7 \%)$ had severe depression. When the patients were divided into two groups as mild and moderate-severity according to Beck Depression Inventory, When the patients were divided into 2 groups according to the Beck depression scale, there was no statistically significant difference between the two groups in terms of gender, age, marital status, education level, income level, duration of complaint, and the reason for admission $(\mathrm{p}=0.164, \mathrm{p}=0.152, \mathrm{p}=0.071, \mathrm{p}=0.096, \mathrm{p}=0.151, \mathrm{p}=0.368, \mathrm{p}=0.317$, respectively).

\section{Discussion}

It was found that $29.50 \%$ of the patients admitted to the emergency department with dermatological complaints were true emergency cases, which was the main result of our study. The patients admitted to the emergency department frequently because they thought that their current conditions were urgent, and, moderate-severe anxiety symptoms were higher in women than in men according to Beck Anxiety Inventory. There were no significant differences between the two groups in terms of demographic data, admission reasons according to Beck Depression Inventory scores.

Murr et al. defined the true dermatologic emergency concept as acute or worsening dermatoses within the last 5 days. ${ }^{8}$ In a pilot study, it was stated that the diagnosis of cellulitis and soft tissue infection was made too much by emergency physicians, but the diagnosis of $20 \%$ of these diseases was changed by infection disease or dermatology consultation. ${ }^{9}$ In our study, it was observed that $29.50 \%$ of the patients who admitted to the emergency department had true emergency condition and the correct dermatological diagnosis rate in the emergency room was $47.50 \%$. Therefore, we 
Evaluation of The Relevance of Urgency in Dermatological Patients Admitted to The Emergency Department with The Relationship Between Anxiety, Depression Levels and Dermatological Quality of Life: A Prospective Observational Study

believe that it is important to have an expert opinion in the diagnosis and treatment of dermatoses that are similar to the ones that can be confused with real disease and it makes the differential diagnosis in dermatology more clearly. In another study conducted in our country, it was stated that the most common diagnosis of dermatological diseases in the emergency department was skin and subcutaneous infections, especially viral origin, and $76 \%$ of the cases did not require urgent intervention. ${ }^{4}$

The early and accurate diagnosis of skin diseases is an important issue that should be considered. Otherwise, they cause the difficulty of treatment or prolongation of convalescence and may lead to repeated hospital admissions due to chronic dermatologic diseases.

The burden of emergency services is increased and unfortunately, the quality and the time allocated to the patients who are in critical conditions are declined. Although dermatological admissions are in the category of green areas more frequently (no need for urgent intervention) hospital admission of dermatologic cases are increased due to the fact that individuals pay less for emergency admissions, and even if they are not true patients for the yellow-red area code, they have the change to be examined by physicians. In our study, the most common reasons of the admission to the emergency department were that the patients thought their illness urgent, they could not take an appointment from the outpatient clinic, and they could not come to the outpatient clinic during the day.

Although $76.5 \%$ of the patients did not have additional comorbid diseases, $70.50 \%$ of them admitted to the emergency room for skin diseases for the first time, anxiety levels about their diseases were high, and they could not know exactly what the concept of dermatological emergency, but they admitted to the emergency department because they could reach a doctor more easily and obtained practical results. In addition, the fact that $63.50 \%$ of the patients' income level had no income or minimum wage might affect their socio-cultural infrastructure and anxiety levels and caused this situation. It is thought that the emergency admissions of the patients can be reduced by working on these reasons.

In skin diseases; psychogenic stress, shyness, physical discomfort, and social activities should not be considered as a result of a change in quality of life that is evaluated only by the severity of the disease. Therefore, a more holistic approach is required in evaluating disease severity by both physical and psychogenic measures. ${ }^{10}$ There have been studies investigating the relationship between anxiety, depression, dermatological quality life and specific diseases such as acne, psoriasis and chronic urticarial. ${ }^{11-13}$

In our study, almost $22,50 \%$ of patients' life quality was not impaired, $77.50 \%$ of the patients were found to have moderate to severe adverse effects according to the mean DLQI. Although the number of patients in an urgent condition was low, it was observed that every disease group with dermatological complaints affects the quality of life of the individuals in a negative way.

In a study similar to the results of our study, it was stated that the quality of life in women with dermatologic diseases admitted to the emergency room was affected at a 
Evaluation of The Relevance of Urgency in Dermatological Patients Admitted to The Emergency Department with The Relationship Between Anxiety, Depression Levels and Dermatological Quality of Life: A Prospective Observational Study

moderate level because women were worried about their health more than men and their cosmetic perception was higher than in men. ${ }^{14}$ Considering that depression and anxiety are cardinal clinical findings in skin diseases, we think that the disease perception rather than disease severity direct patients to emergency services immediately.

Limitations: The data were composed of verbal expressions and patients selected by the physician's objective observations and there was no psychiatric consultation. In addition, the patient with every dermatological problem admitted to the emergency department did not receive dermatology consultation and the pediatric population was not included in the study, so the results could not be generalized to include this group. The evaluation of the patients admitted to the emergency department only in 3 months period might be limited in terms of reflecting the results to the general population.

\section{Conclusion}

Emergency clinics are vital. It is the main responsibility to reduce the time loss with an effective triage and to provide the necessary quick approach to the individuals who are really urgent. However, the number of patients admitted to emergency clinics has been increased and the dermatological patient group has occupied the emergency services, although they have not suitable for the dermatological emergency definition.

In our study, the patients who came from the emergency department were evaluated by dermatology physician in a short time and more accurate diagnosis and rapid treatment opportunities were provided. Therefore, unnecessary medical approaches and high costs were prevented.

We believe that increased anxiety levels are an important factor in patients admitting to the emergency department. Therefore, awareness-raising campaigns should be beneficial in preventing frequent admission by social media and hospital-based campaigns focusing on this issue. In addition, the majority of patients in our study (such as urticaria, zona, contact dermatitis) were found to be easily diagnosed and managed by a general practitioner without having to be evaluated by a dermatologist. From the dermatological point of view, it is possible to reduce the urgent intensity with the training to be given to physicians in the ist stage health service points.

\section{References}

1- Grillo S, Vano-Galvan N, Jiménez-Gómez A, Ballester A, Muñoz-Zato E, Jaén P . Dermatologic Emergencies:Descriptive Analysis of 861 Patients in a Tertiary Care Teaching Hospital. Actas Dermosifiliogr 2013;104:316-24.

2- Jack AR, Spence AA, Nichols BJ, Chong S, Williams DT, Swadron SP, et al. Cutaneous Conditions Leading to Dermatology Consultations in the Emergency Department. West J Emerg Med 2011;12:551-5.

3- Erdogan HK, Altunay IK, Koslu A. Evaluation of dermatologic emergency patients: a unicentral prospective clinical study. Arch Turkish Dermatol Venereol. 2009; 43: 144-8.

4- Ozkur E, Altunay IK, Sekerlisoy G, Erdem Y. Dermatology consultations in a tertiary care centre emergency service. The Medical Bulletin of Sisli Etfal Hospital 2018.

5- Öztürkcan S, Ermertcan AT, Eser E, Fiahin MT: Cross validation of the Turkish version of dermatology life quality index. Int J Dermatol 2006;45:1300-7.

6- Eren I, Sahin M, Tunc SE, Cure E, Civi II: Psychiatric symptoms and quality of life in patients 
Evaluation of The Relevance of Urgency in Dermatological Patients Admitted to The Emergency Department with The Relationship Between Anxiety, Depression Levels and Dermatological Quality of Life: A Prospective Observational Study

with Behçet's disease. Neurol Psychiatr Brain Res 2006;13:169-74.

7- Faul F., Erdfelder E., Buchner A., Lang A.G., Statistical power analyses using G power 3.1: tests for correlation and regression analyses. Behav Res Methods 2009; 41: 1149-6o.

8- Murr D, Bocquet H, Bachot N, Bagot M, Revuz J, Roujeau JC: Intérêt d'une consultation hospitalière d'urgences dermatologiques. Ann Dermatol Venereol 2003; 130:167-70.

9- Craft N, Robbin D, Manassi L, Art P. Overdiagnosis of cellulitis and soft tissue infections: designing decision support systems to reduce predictable diagnostic error. Paper presented at: AHRQ/AMIA Diagnostic Error in Medicine National Conference; May 31, 2008; Phoenix, Arizona.

10- Jayaprakasam A, Darvay A, Osborne G, McGibbon D. Comparison of assessments of severity and quality of life in cutaneous disease. Clin Exp Dermatol. 2002; 27:306-8.

11- Yazici K, Baz K, Yazici AE, Köktürk A, Tot S, Demirseren D, Buturak V. Disease-specific quality of life is associated with anxiety and depression in patients with acne. J Eur Acad Dermatol Venereol. $2004 ; 18: 435-9$.

12- Schmitt J, Küster D. Correlation between Dermatology Life Quality Index (DLQI) scores and Work Limitations Questionnaire (WLQ) allows the calculation of percent work productivity loss in patients with psoriasis. Arch Dermatol Res. 2015;307:451-3.

13- Engin B, Uguz F, Yilmaz E, Ozdemir M, Mevlitoglu I. The levels of depression, anxiety and quality of life in patients with chronic idiopathic urticaria. J Eur Acad Dermatol Venereol. $2008 ; 22: 36-40$.

14- Alegre-Sánchez A, de Perosanz-Lobo D, Pascual-Sánchez A, Pindado-Ortega C,Fonda-Pascual P, Moreno-Arrones ÓM, Jaén-Olasolo P. Impact on Quality of Life in Dermatology Patients Attending an Emergency Department. Actas Dermosifiliogr. 2017 ; 108:918-23. 